JURNAL WARTA FARMASI
Volume 8 | Nomor 2 | Oktober | 2019
ISSN: 2089-712X

\title{
Uji Efek Antidiabetik Ekstrak Daun Trembesi (Albizia saman (Jacq.) Merr) Terhadap Mencit (Mus musculus L)
}

\section{Antidiabetic Effect Of Trembesi Leaf Extract (Albizia saman (Jacq.) Merr) Against Mencit (Mus musculus L)}

\author{
Muh. Azdar Setiawan*, Muh. Syaiful Saehu, Kartini \\ Politeknik Bina Husada Kendari, Program Studi DIII Farmasi \\ Jl. Sorumba No. 17 Kendari - Sulawesi Tenggara 93117, Tlp./Fax : 0401-390193 \\ Email : muhazdar86@gmail.com,syaiful_saehu@yahoo.co.id
}

\begin{abstract}
ABSTRAK
Daun trembesi (Albizia saman (Jacq.) Merr) adalah salah satu tanaman berkhasiat menurunkan kadar glukosa darah dimana kandungan kimianya berpotensi menurunkan kadar glukosa darah antara lain flavonoid yang bekerja dengan cara menstimulasi sel- sel beta dari pulau langerhans, sehingga sekresi insulin ditingkatkan.Penelitian ini bertujuan untuk mengetahui efek antidiabetes ekstrak daun trembesi (Albizia saman (Jacq.) Merr) pada mencit (Mus musculus). Metode Penelitian ini merupakan penelitian Eksperimen dimana sebanyak 20 ekor mencit dibuat diabetes dengan menggunakan Streptozotosin $150 \mathrm{mg} / \mathrm{kgBB}$ secara Intraperitonial. Kemudian dibagi menjadi 5 kelompok perlakuan, yaitu: Ekstrak dosis $25 \mathrm{mg} / \mathrm{kgBB}, 50$ $\mathrm{mg} / \mathrm{kgBB}, 100 \mathrm{mg} / \mathrm{kgBB}$, sebagai kontrol positif Glibenclamid $5 \mathrm{mg}$ dan kontrol negatif suspensi Na.CMC 0,5\%. Data yang diperoleh dianalisis dengan uji ANOVA. Hasil analisa statistik menunjukan pada konsentrasi ekstrak 100 mg/kgBB memberikan efek yang optimum dengan perlakuan kontrol positif Glibenklamid.
\end{abstract}

Kata Kunci : Ekstrak Daun Trembesi, Antidiabetik.

\begin{abstract}
Trembesi leaf (Albizia saman (Jacq.) Merr) is one of the efficacious plants to reduce blood glucose levels where the chemical content has the potential to reduce blood glucose levels, among others, flavonoids that work by stimulating beta cells of the island langerhans, so that insulin secretion is increased. It aims to determine the antidiabetic effect of trembesi leaf extract (Albizia saman (Jacq.) Merr) in mice (Mus musculus). This research method is an experimental study in which as many as 20 mice were made diabetic using Streptozotosin $150 \mathrm{mg} /$ $\mathrm{kgBW}$ intraperitonially. Then divided into 5 treatment groups, namely: Extract dose $25 \mathrm{mg} / \mathrm{kg}$ body weight, 50 $\mathrm{mg} / \mathrm{kg}$ body weight, $100 \mathrm{mg} / \mathrm{kg}$ body weight, as positive control Glibenclamid $5 \mathrm{mg}$ and negative control suspension Na.CMC 0.5\%. The data obtained were analyzed by ANOVA test. The results of statistical analysis showed that the extract concentration of $100 \mathrm{mg} / \mathrm{kgBB}$ gave the optimum effect with the positive control of Glibenclamide.
\end{abstract}

Keywords: Trembesi Leaf Extract, Antidiabetic. 


\section{PENDAHULUAN}

Diabetes melitus (DM) merupakan penyakit gangguan metabolik menahun akibat pankreas tidak memproduksi cukup insulin atau tubuh tidak dapat menggunakan insulin yang diproduksi secara efektif. Insulin adalah hormon yang mengatur keseimbangan kadar glukosa darah (Kemenkes, 2014).

Prevalensi kejadian kasus DM berdasarkan umur penduduk indonesia $\geq 15$ tahun terdapat peningkatan antara 2013-2018 pada tahun 2013 terdapat 1,5\% sedang pada tahun 2018 terdapat $2.0 \%$ sebagaimana yang telah yang dipublikasikan oleh Kementrian Kesehatan (2018), sekitar 528,32 orang atau $2,0 \%$ dari jumlah penduduk indonesia menderita DM. Untuk wilayah Sulawesi Tenggara masih di bawah $2.0 \%$ dari jumlah penderita DM dari jumlah penderita DM nasional. sekitar 3206 orang atau $0,12 \%$ dari jumlah penduduk Sulawesi Tenggara menderita DM.

Menurut profil kesehatan provinsi sulawesi tenggara pada tahun 2012 jumlah penderita penyakit Diabetes Melitus (DM) sebanyak 3.501 orang, sedangkan pada tahun 2016 jumlah penderita penyakit Diabetes Melitus (DM) sebanyak 3.206 orang.

Menurut Yunita (2013), dalam mengatasi diabetik, obat perlu diberikan bila diet yang dijalankan tidak berhasil mengendalikan kadar glukosa darah. Obat antidiabetik oral mungkin berguna untuk penderita yang alergi terhadap insulin atau yang tidak menggunakan suntikan insulin. Obat antidiabetik oral kebanyakan memberikan efek samping yang tidak diinginkan, maka para ahli mengembangkan sistem pengobatan tradisional untuk diabetik melitus yang relatif aman.

Tanaman trembesi dapat mencapai ketinggian rata-rata 20-25 m. Bentuk batangnya tidak beraturan, dengan daun majemuk yang panjangnya sekitar $7-15 \mathrm{~cm}$, sedangkan pada pohon trembesi yang sudah tua berwarna kecoklatan, permukaan kulit kasar, dan terkelupas. Bunga tanaman ini berwarna putih dengan

bercak merah muda pada bagian bulu atasnya, panjang bunga mencapai $10 \mathrm{~cm}$ dari pangkal bunga hingga ujung bulu bunga. Bunga trembesi menghasilkan nektar untuk menarik serangga guna berlangsungnya proses penyerbukan. Buah trembesi berwarna coklat kehitaman ketika buah sudah masak, dengan biji tertanam dalam daging buah (Dahlan, 2010).

Salah satu tambahan yang dipercaya dapat digunakan dalam pengobatan tradisional adalah tanaman trembesi. Daun trembesi memiliki kegunaan lainnya yaitu dapat pula digunakan sebagai bahan obat tradisional 
seperti diare, demam, sakit perut, dan sakit kepala. Skrining fitokimia menunjukkan adanya senyawa metabolit sekunder yaitu tanin, selain tanin daun trembesi juga mengandung flavonoid, saponin, steroid, terpenoid, dan glikosida kardiak dalam ekstrak daun trembesi. Senyawa-senyawa tersebut diyakini dapat berpotensi sebagai antidiabetes.

\section{METODE PENELITIAN}

Desain atau rancangan penelitian merupakan kerangka acuan bagi peneliti untuk mengkaji hubungan antar variabel dalam suatu penelitian ( Riyanto, 2011). Desain penelitian yang digunakan dalam Uji Efek Antidiabetik Ekstrak Daun Trembesi (Albizia saman (Jacq.) Merr) terhadap mencit (Mus musculus L.) menggunakan rancangan eksperimen ulang yaitu desain pretes - postes dengan kelompok kontrol (pretes - posttest with control group) yang terdiri atas lima perlakuan, dan empat kali replikasi

\section{Alat dan Bahan}

Alat yang digunakan yaitu batang pengaduk, botol kaca, clanula, gelas ukur Pyrex $^{\circledR} 100 \mathrm{~mL}$, gelas kimia Pyrex ${ }^{\circledR} 50 \mathrm{~mL}$, glukometer, gunting, kain flanel, rotary vacum evapavor, hot plate, mortir dan stamfer, spoit $1 \mathrm{ml}$, sendok tanduk, timbangan analitik, dan strip gula darah (Easy Touch GCU).
Bahan yang digunakan Aquadest, etanol 96\%, glibenklamid $5 \mathrm{mg}$, Na.CMC 0,5\%, Simplisia Daun trembesi 500 gram dan Streptozotosin.

\section{Pengambilan dan Pengolahan sampel}

Sampel diambil di desa Wawoluri, kabupaten Konawe Utara dengan menggunakan alat. Disortasi basah dan dicuci sampel dengan air mengalir, kemudian ditiriskan. Dirajang kecil-kecil sampel daun trembesi dan dikeringkan sampel dibawah sinar matahari ditutupi kain berwarna hitam. Disortasi kering sampel kemudian, simplisia kering ditimbang.

\section{Pembuatan ekstrak}

Dimasukkan simplisia daun trembesi kedalam wadah maserasi. Ditambahkan pelarut etanol $96 \%$ hingga sampel simplisia terendam.Dibiarkan selama 3-5 hari sambil sesekali diaduk. Setelah proses ekstraksi pertama selesai, ampasnya dimaserasi kembali dengan cairan penyari yang baru.

\section{Pemekatan Ekstrak}

Ekstrak yang diperoleh lalu dipekatkkan dengan menggunakan alat Rotary Vacum Evaporator hingga di peroleh ekstrak kental.

\section{CARA KERJA}

Cara kerja perlakuan hewan uji yaitu disiapkan alat dan bahan yang akan digunakan.Ditimbang masing-masing hewan uji (mencit). Diambil darah masing-masing mencit melalui vena ekornya untuk 
mengukur kadar glukosa darah awal. Di induksikan dengan larutan sterptozotocin 0,2 $\mathrm{mL}$ secara intraperitonial, kemudian dibiarkan selama 18-48 jam, lalu diberikan larutan sukrosa selama 24 jam secara atlibitium. Diukur kadar glukosa darah setelah induksi streptozotocin. Kemudian diberikan perlakuan melalui oral pada mencit selama 7 hari, Kelompok I diberikan ekstrak daun trembesi dosis $25 \mathrm{mg} / \mathrm{kgBB}$, Kelompok II diberikan ekstrak daun trembesi dosis 50 $\mathrm{mg} / \mathrm{kgBB}$, Kelompok III diberikan ekstrak daun trembesi dosis $100 \mathrm{mg} / \mathrm{kgBB}$ Kelompok IV diberikan kontrol Na.CMC 0,5\% kelompok $\quad \mathrm{V}$ diberikan suspensi Glibenklamid sesuai volume. Kemudian dilakukan pengukuran kadar glukosa darah masing-masing mencit pada hari ke- 8 dan dicatat hasilnya.

\section{HASIL DAN PEMBAHASAN}

Telah dilakukan penelitian uji efek antidiabetik ekstrak daun Trembesi (Albizia saman (Jacq.) Merr) pada mencit di Laboratorium Farmakologi Politeknik Bina Husada Kendari. Menggunakan sampel tumbuhan daun Trembesi (Albizia saman (Jacq.) Merr. yang diambil di Desa wawoluri, Kabupaten Konawe Utara, Sulawesi Tenggara. Langkah awal dalam penelitian ini yaitu dengan membuat simplisia kering daun Trembesi (Albizia saman (Jacq.) Merr. Pembuatan simplisia daun trembesi diawali
Dengan proses pemanenan daun trembesi. Daun trembesi memiliki tekstur yang lunak sehingga pemanenan dilakukan secara manual, daun yang Dipetik yaitu daun muda yang segar. Pemanenan daun dilakukan pada pukul 09.30 WITA dimana pada saat itu daun mengalami proses fotosintesis yang bertujuan untuk mendapatkan senyawa bioaktif yang lebih baik (Guntur, I., 2016). Daun trembesi yang telah dikumpulkan kemudian disortasi basah dengan tujuan untuk menghilangkan kotoran-kotoran atau bahan-bahan asing lainya dari sampel. Setelah disortasi basah buah trembesi kemudian dicuci pada air mengalir, pencucian dilakukan untuk menghilangkan tanah dan kotoran lainnya yang melekat pada sampel. Pencucian dilakukan dalam waktu sesingkat mungkin karena kemungkinan terdapat beberapa zat yang terkandung dalam simplisia dapat larut dalam air mengalir (Irwan, 2017).

Setelah proses pencucian, kemudian daun trembesi dirajang kecil-kecil untuk mempermudah proses pengeringan dan memperluas permukaan, sehingga pada proses ekstraksi, kontak antara pelarut dengan sampel lebih efektif dan senyawa dapat terekstraksi dengan optimal, selanjutnya daun yang telah dirajang kemudian dikeringkan pada suhu ruang hingga kadar air yang terkandung dalam sampel berkurang. Sampel yang telah 
kering kemudian diekstraksi dengan metode maserasi menggunakan pelarut etanol $96 \%$, penggunaan metode ekstraksi secara maserasi yaitu dengan melihat sifat zat aktif dari daun trembesi yaitu senyawa flavanoid yang akan ditarik memiliki sifat yang tidak tahan terhadap panas, kemudian metode ini sesuai digunakan untuk simplisia bertekstur lunak, proses pengerjaannya yang mudah serta peralatan yang digunakan sederhana.

\section{Penggunaan Etanol 96\%} dipertimbangkan sebagai cairan penyari karena Senyawa fenolik dan flavonoid umumnya mudah larut dalam air karena sering kali berikatan dengan gula sebagai glikosida (Setiawan, Hasnawati, Sernita, \& Sulistia, 2016),oleh karena itu untuk meningkatkan keefektifan penyarian, umumnya menggunakan campuran bahan pelarut yang berlainan, khususnya campuran etanol dan air. Etanol dapat bercampur dengan air pada segala perbandingan dan panas yang diperlukan untuk pemekatan lebih sedikit. Proses ekstraksi maserasi dilakukan selama 5 hari pada suhu kamar dan terllindung dari cahaya. Selanjutnya maserat dirotary evaporator untuk mempekatkan sehingga diperoleh ekstrak kental, (Irwan, 2017).

Tumbuhan daun trembesi dilaporkan dapat menunjukkan efek hipoglikemik, diamana pada daun trembesi mengandung alkaloid, flavonoid, tannin, saponin, terpenoid, dan steroid. Dimana senyawa golongan flavonoid, saponin dan tannin dapat mengobati diabetes mellitus dengan cara menghambat kerja enzim alfa-glukosidase dalam memecah karbohidrat menjadi gula sederhana dan sebagai antioksidan yang akan menurunkan tingkat stress oksidatif penderita diabetes mellitus. Flavonoid berkhasiat sebagai antidiabetik bekerja melalui kemampuan mengurangi penyerapan glukosa darah maupun dengan cara meningkatkan toleransi glukosa (Brahmachari, 2011). Berdasarkan hasil penelitian uji efek antidiabetik ekstrak daun trembesi terhadap penurunan kadar glukosa darah mencit model diabetes diperoleh hasil penurunan kadar glukosa darah, sebagai berikut :

Tabel 1 : Hasil Pengukuran Kadar Gula Darah Mencit Sebelum Sesudah Dan Setelah Perlakuan

\begin{tabular}{|c|c|c|c|c|c|c|}
\hline \multirow[b]{2}{*}{ No } & \multirow[b]{2}{*}{ Perlakuan } & \multirow[b]{2}{*}{ Replikasi } & \multicolumn{3}{|c|}{ Kadar Glukosa Darah (mg/dL) } & \multirow{2}{*}{$\begin{array}{c}\text { Selisih } \\
\text { Penurunan } \\
\text { Efek } \\
\text { Antidiabetes } \\
\text { (mg/dL) }\end{array}$} \\
\hline & & & Awal & $\begin{array}{c}\text { Setelah } \\
\text { pemberian } \\
\text { Streptozotosin }\end{array}$ & $\begin{array}{c}\text { Setelah } \\
\text { perlakuan } \\
\text { setelah } 7 \text { hari }\end{array}$ & \\
\hline 1 & Ekstrak etanol 25 & 1 & 70 & 233 & 169 & 64 \\
\hline
\end{tabular}


Uji Efek Antidiabetik Ekstrak Daun Trembesi (Albizia saman (Jacq.) Merr) Terhadap Mencit (Mus musculus L), Muh. Azdar Setiawan, dkk, Hal. 43 - 52

\begin{tabular}{|c|c|c|c|c|c|c|}
\hline \multirow{3}{*}{\multicolumn{2}{|c|}{$\mathrm{mg} / \mathrm{kgBB}$}} & 2 & 68 & 213 & 180 & 33 \\
\hline & & 3 & 91 & 217 & 171 & 46 \\
\hline & & 4 & 119 & 215 & 179 & 36 \\
\hline & $\sum$ & & & 878 & 699 & 179 \\
\hline & Rata-rata & & & 219.5 & 174.75 & 44.75 \\
\hline \multirow{6}{*}{2} & & 1 & 76 & 223 & 153 & 70 \\
\hline & Ekstrak etanol 50 & 2 & 121 & 198 & 135 & 63 \\
\hline & $\mathrm{mg} / \mathrm{kgBB}$ & 3 & 109 & 214 & 140 & 74 \\
\hline & & 4 & 88 & 212 & 126 & 86 \\
\hline & $\sum$ & & & 847 & 554 & 293 \\
\hline & Rata-rata & & & 211.75 & 138.5 & 73.25 \\
\hline \multirow{6}{*}{3} & & 1 & 85 & 216 & 120 & 96 \\
\hline & Ekstrak etanol 100 & 2 & 90 & 233 & 118 & 115 \\
\hline & $\mathrm{mg} / \mathrm{kgBB}$ & 3 & 87 & 201 & 115 & 86 \\
\hline & & 4 & 86 & 211 & 110 & 101 \\
\hline & $\sum$ & & & 861 & 463 & 398 \\
\hline & Rata-rata & & & 215.25 & 115.75 & 99.5 \\
\hline \multirow{6}{*}{4} & & 1 & 77 & 205 & 98 & 107 \\
\hline & $\begin{array}{l}\text { Suspensi } \\
\text { Sibentlomid }\end{array}$ & 2 & 82 & 210 & 103 & 107 \\
\hline & Glibenklamid & 3 & 89 & 210 & 99 & 111 \\
\hline & (Kontrol Positif) & 4 & 79 & 197 & 102 & 95 \\
\hline & $\sum$ & & & 822 & 402 & 420 \\
\hline & Rata-rata & & & 205.5 & 100.5 & 105 \\
\hline \multirow{6}{*}{5} & & 1 & 88 & 223 & 227 & -4 \\
\hline & & 2 & 86 & 201 & 210 & -9 \\
\hline & Na. CMC 0,5 \% & 3 & 90 & 211 & 205 & 6 \\
\hline & & 4 & 82 & 217 & 221 & -4 \\
\hline & $\sum$ & & & 852 & 863 & -9 \\
\hline & Rata-rata & & & 213 & 215.75 & -3 \\
\hline
\end{tabular}

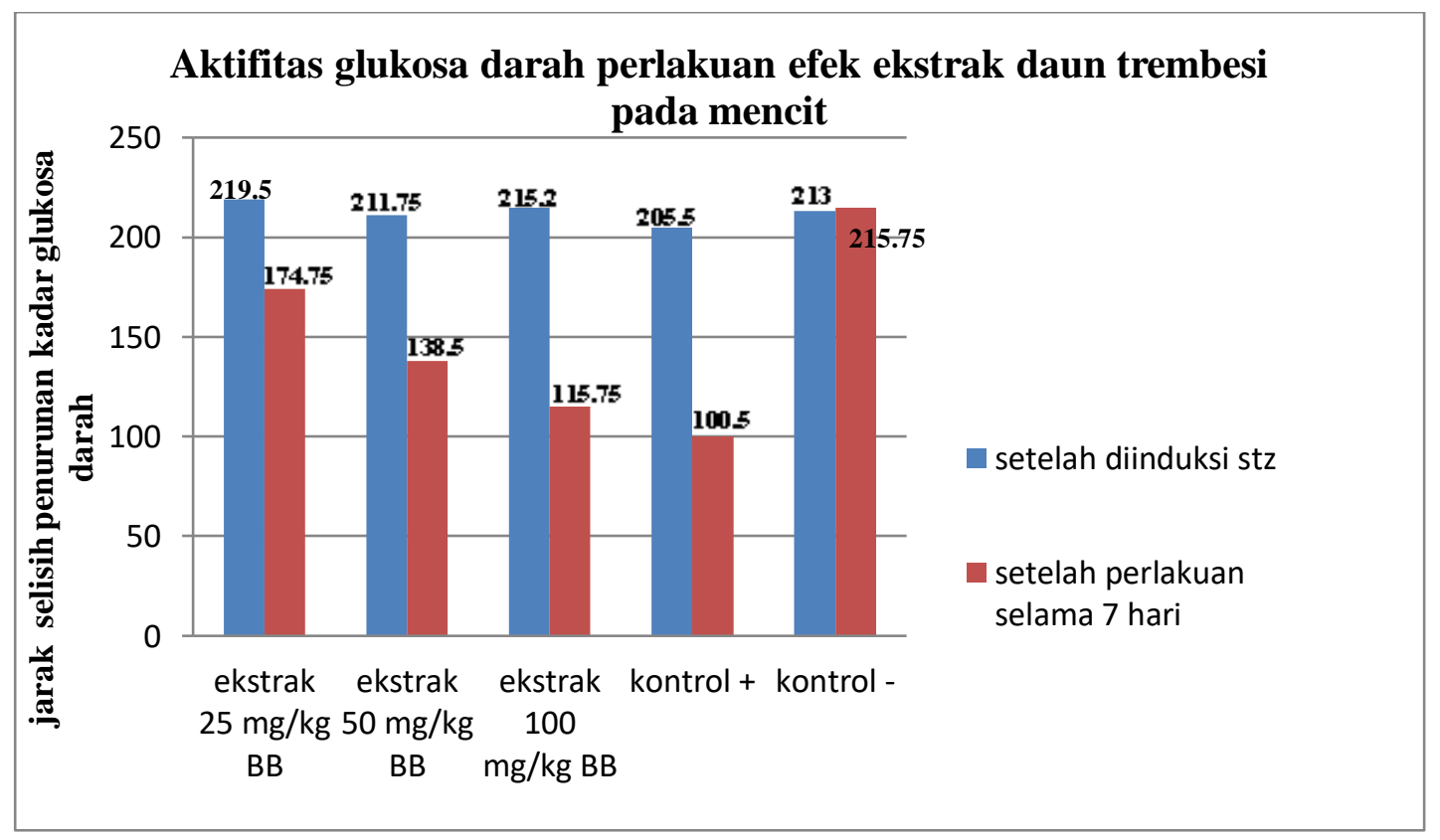

Naskah diterima : 10 September 2019, diterima untuk diterbitkan 20 September 2019, diterbitkan 10 Oktober 2019 


\section{Grafik 1. Rata- Rata Penurunan Kadar Glukosa Darah}

Penelitian ini dilakukan untuk melihat efek penurunan kadar gula darah dari ekstrak daun trembesi pada mencit dengan konsentrasi yang digunakan dalam penelitian ini adalah $25 \mathrm{mg} / \mathrm{kgBB}, 50$ $\mathrm{mg} / \mathrm{kgBB}$, dan $100 \mathrm{mg} / \mathrm{kgBB}$.

Kontrol positif digunakan glibenclamid. Glibenclamid merupakan obat antidiabetes oral golongan sulfonilurea. Obat ini bekerja dengan cara merangsang sekresi insulin dipankreas dan menghambat peghancuran insulin oleh hati. Sedangakan Na.CMC digunakan sebagai kontrol negatif dan juga untuk memudahkan pada saat pemberian sediaan pada mencit.

Penelitian ini menggunakan 20 ekor mencit yang dibagi menjadi 5 kelompok. Tiap kelompok terdiri dari 4 ekor. Pada penelitian ini menggunakan 3 kelompok kontrol yaitu kelompok kontrol normal atau kelompok ekstrak, kontrol negatif, dan kontrol positif. Penggunaan kontrol positif dimaksudkan untuk melihat sejauh mana efek obat pembanding (Glibenklamid $5 \mathrm{mg}$ ) mampu menurunkan kadar Glukosa darah pada mencit yang menderita Diabetes dibandingkan kelompok normal dan kontrol negatif.
Pengukuran kadar glukosa darah mencit dilakukan dengan menggunakan alat Easy Touc. Alat ini harus dicek terlebih dahulu dengan memasang batrei, kode stip glukosa dan stip glukosa yang akan digunakan sebelum dilakukan pengukuran kadar glukosa darah mencit. Pengambilan darah mencit dilakukan sebanyak 3 kali. Pertama hari ke 1 untuk mengukur kadar glukosa darah puasa, hari ke 2 setelah penginduksian streptozotosin (STZ) dan hari ke 8 setelah pemberian ekstrak. Sebelum pengambilan darah dilakukan puasa terhadap mencit \pm 16 jam dengan tujuan untuk menghindari meningkatnya kadar glukosa darah yang akan diuji. Penginduksian streptozotosin dilakukan secara i.p dengan dosis $150 \mathrm{mg} / \mathrm{kg}$ BB. Penggunaan streptozotosin bertujuan untuk merusak DNA sel-sel pulau pankreas, dan menstimulasi sintesis poli nuklear (ADPribosa), NAD, dan NADP yang kemudian akan menghambat atau menghalangi sintesis proinsulin dan akhirnya menyebabkan diabetes.

Menurut Kusumawati (2014) larutan streptozotosin $150 \mathrm{mg} / \mathrm{kg}$ bb secara intraperitonial diberikan pada mencit 18 jam sebelum pemberian sediaan uji yang bertujuan untuk menaikkan kadar glukosa 
darah dari kadar glukosa awal, sehingga kemampuan menurunkan glukosa darah dari sediaan uji dapat diamati.

Pada kelompok perlakuan dosis 25 $\mathrm{mg} / \mathrm{kgBB}$ ekstrak daun trembesi, pengukuran kadar gula awal atau normal diperoleh $87 \mathrm{mg} / \mathrm{dL}$, kemudian kadar gula darah setelah di induksi streptozotosin menjadi $219.5 \mathrm{mg} / \mathrm{dL}$. Selanjutnya pengukuran kadar gula darah setelah perlakuan yaitu dengan pemberian ekstrak daun trembesi dosis $25 \mathrm{mg} / \mathrm{kgBB}$ adalah 174,75 mg/dL. Perlakuan kelompok ke dua dengan dosis $50 \mathrm{mg} / \mathrm{kgBB}$ ekstrak daun trembesi, pengukuran kadar gula awal atau normal diperoleh 98,5 mg/dL, kemudian kadar gula darah setelah di induksi streptozotosin menjadi 211,75 $\mathrm{mg} / \mathrm{dL}$. Selanjutnya pengukuran kadar gula darah setelah perlakuan yaitu dengan pemberian ekstrak daun trembesi dosis $50 \mathrm{mg} / \mathrm{kgBB}$ adalah 138,5 mg/dL. Perlakuan kelompok ke tiga dengan dosis $100 \mathrm{mg} / \mathrm{kgBB}$ ekstrak daun trembesi, pengukuran kadar gula awal atau normal diperoleh $87 \mathrm{mg} / \mathrm{dL}$, kemudian kadar gula darah setelah di induksi streptozotosin menjadi $215,25 \mathrm{mg} / \mathrm{dL}$. Selanjutnya pengukuran kadar gula darah setelah perlakuan yaitu dengan pemberian ekstrak daun trembesi dosis $100 \mathrm{mg} / \mathrm{kgBB}$ adalah 115,75 mg/dL.
Perlakuan kelompok Positif suspensi Glibenklamid pengukuran kadar gula awal atau normal diperoleh 81,75 mg/dL, kemudian kadar gula darah stelah di induksi streptozotosin menjadi 205,5 $\mathrm{mg} / \mathrm{dL}$. Selanjutnya pengukuran kadar gula darah setelah perlakuan yaitu dengan pemberian suspensi glibenklamid adalah, 100,5 mg/dL. Perlakuan kelompok Negatif Na. CMC pengukuran kadar gula awal atau normal diperoleh, 86,5 mg/dL kemudian kadar gula darah stelah di induksi streptozotosin menjadi, $213 \mathrm{mg} / \mathrm{dL}$. Selanjutnya pengukuran kadar gula darah setelah perlakuan yaitu dengan pemberian suspensi Na. CMC adalah, $215.75 \mathrm{mg} / \mathrm{dL}$.

Berdasarkan diagram grafik yang terdapat pada gambar 12. Dapat dilihat bahwa rata-rata penurunan glukosa darah pada mencit yang terjadi pada tiap perlakuan menunjukkan bahwa ekstrak daun trembesi $100 \mathrm{mg} / \mathrm{kgBB}$ yaitu merupakan penurunan glukosa darah yang hampir sama dengan perlakuan dari suspensi glibenklamid sebagai kontrol positif, dibandingkan dengan perlakuan yang lain yaitu ekstrak daun trembesi 25 $\mathrm{mg} / \mathrm{dL}$ dan ekstrak daun trembesi 50 $\mathrm{mg} / \mathrm{dL}$.

Penurunan glukosa darah yang tejadi pada setiap perlakuan ekstrak daun trembesi diduga berasal dari senyawa aktif 
berupa flavonoid, dimana flavonoid bekerja dengan cara menstimulasi sel-sel beta dari pulau langerhans, sehingga sekresi insulin ditingkatkan (Victoria, 2012).

Pada uji data secara statistik menggunakan one way-Anova pada aplikasi IBM spss 22.0. pengujian ini digunakan untuk mengetahui apakah terjadi perbedaan yang signifikan dari tiap perlakuan kelompok berdasarkan selisih penurunan kadar glukosa darah. Pengujian spss yang pertama dilakukan adalah uji deskriptif dimana untuk melihat rata-rata dari msingmasing konsentrasi dan untuk melihat efek penurunan minimum dan maksimum suatu konsentrasi. Kemudian dilanjutkan dengan uji homogenitas dilakukan sebelum uji anova, dimana data dikatakan homogen bila nilai sig. lebih besar dari 0.05 dan data tidak homogen bila nilai sig. lebih kecil dari 0.05 . bila niali tidak homogen uji anova tidak bisa dilakukan. Kemudian di lanjutkan

Uji anova dilakukan untuk mengetahui ada atau tidak perbedaan dari masing-masing konsentrasi. Dimana bila nilai sig. lebih kecil dari 0.05 maka data dikata berbeda signifikan dari masing konsentrasi dalam menurunkan kadar glukosa. Uji ini hanya untuk mengetahui ada atau tidak perbedaan antara msingmasing konsentrasi dalam menurunkan kadar glukosa, tetapi tidak bisa menunjukan konsentrasi berpa yang berbeda signifikan. Sedangkan untuk mengetahui konsentrasi berapa yang berbeda signifikan harus dilakukan dengan uji lanjutan yaitu uji tukey atau LSD. Dimana Uji tukey adalah uji lanjutan dari uji anova yang dilakukan untuk mengetahui lebih lanjut pada konsentrasi berapa terjadi berbedaan signifikan. Dimana bila nilai sig. lebih besar dari 0.05 maka tidak terdpat perbedaan atau hampir sama. Sedangkan bila nilai sig. lebih kecil dari 0.05 maka terdapat perbedaan dari masing konsentrasi. Unutk lebih mudah menganalisa pada uji LSD bila langsung melihat tabel pada kolom (Mean Difference (I-J)) bila tidak terdapat tanda (*) pada nilai dikolom (Mean Difference (I-J)) maka data dikatan tidak berbeda signifikan atau hampir sama, namun bila terdapat tanda $(*)$ maka data dikatakan berbeda secara signifikan.

Faktor-faktor yang dapat mempengaruhi penelitian antara lain faktor biologis dari mencit seperti, kondisi mencit yang kurang sehat, makanan yang kurang. Pelarut yang digunakan dalam mengekstraksi sampel seperti pelarut yang tidak dapat menarik semua zat-zat yang terkandung dalam sampel. Perbedaan konsentrasi sampel yang digunakan dan penggunaan alat pengukur yang kurang 
kadar gula darah yang digunakan pada saat penelitian.

\section{KESIMPULAN}

1. Efek Ekstrak Daun Trembesi (Albizia saman (Jacq.) Merr) dapat menurunkan kadar Glukosa darah pada Mencit (Mus musculus).

2. Berdasarkan hasil uji LSD, Dosis 25 $\mathrm{mg} / \mathrm{kgBB}$ mulai efektif menurunkan kadar glukosa darah, dan Dosis 100 $\mathrm{mg} / \mathrm{kgBB}$ memiliki efek menurunkan kadar glukosa darah yang paling optimum pada mencit.

\section{UCAPAN TERIMA KASIH}

Kampus Politeknik Bina Husada Kendari yang telah memberikan izin penelitian.

\section{DAFTAR PUSTAKA}

Brahmachari, G., 2011, Bio-Flavonoids With Promising Antidiabetc Patentials.Acritical survey, Rescarch Signpost,187-212

Dahlan, E.N. 2010. Trembesi Dahulunya Asing Sekarang Tidak Lagi. Bogor. IPB Press.

Guntur, I., Kasim, Ma'ruf dan Arami, Hasnia. 2016, Aktivitas fotosintesis pada area budidaya rumput laut dan area non budidaya rumput laut di Perairan Pantai Lakeba Kota Baubau, Fakultas Perikanan dan Ilmu Kelautan Universitas Halu Oleo.
Harborne, J.B., 1996, Metode Fitokimia Penuntun Cara Modern Mengalisis Tumbuhan, Diterjemahkan oleh Kosasih Padmawinata dan Imam Sudiro, Edisi II, Hal 4-7 :69-76, ITB. Bandung.

Irwan, Ayu Setiawan, 2017, Uji aktivitas antimikroa Hasil Fraksinasi Ekstrak Rimpang Jeringat (Acorus calanus L) Terhadap akteri Patogen UIN Alaudin, Makasar.

Kemenkes RI. 2014. Infodatin pusat data dan informasi kementrian kesehatan RI situasi dan analisis diabetes. Jakarta : kemenkes RI

Kusumawati, D. 2014, Bersahabat Dengan Hewan Coba, UGM Press, Yogyakarta.

Riyanto, 2011. Metodologi dan Aplikasi Penelitian Keperawatan. Yogyakarta: Nuha Medika.

Setiawan, M. A., Hasnawati, H., Sernita, S., \& Sulistia, L. (2016). Uji Daya Hambat Antibakteri Fungi Endofit Kulit Jeruk Nipis (Citrus aurantifolia) Terhadap Bakteri Staphylococcus aureus. Jurnal Sains Farmasi \& Klinis, $\quad 3(1), \quad 14$. https://doi.org/10.29208/jsfk.2016.3.1 .90

Viktoria Cyntia Yogya Astuti. 2012. Jurnal Pengaruh Pemberian Ekstrak Daun Kumis Kucing (Orthosiphon aristatus)Terhadap Penurunan Kadar Glukosa Darah Tikus Wistar yang Diinduksi Aloksan. Universitas Ponegoro. Semarang. 